\title{
Status of the fishery of Jaffna lagoon, Sri Lanka
}

\author{
N. $\operatorname{Ragavan}^{1 *}$, D.C.T. Dissanayake ${ }^{2}$ and S. Kuganathan ${ }^{1}$ \\ ${ }^{1}$ Department of Fisheries, University of Jaffna, Sri Lanka \\ ${ }^{2}$ Department of Zoology, University of Sri Jayewardenepura, Gangodawila, Nugegoda
}

*Correspondence (ragavan@univ.jfn.ac.lk)

https://orcid.org/0000-0001-9279-9793

Received: 12.03.2020 Revised: 03.03.2021 Accepted: 05.03.2021 Published online: 15.03.2021

\begin{abstract}
Jaffna lagoon ( $9^{\circ} 50^{\prime} \mathrm{N}$ and $79^{\circ} 50^{\prime} \mathrm{E}$ to $9^{\circ} 20^{\prime} \mathrm{N}$ and $80^{\circ} 30^{\prime} \mathrm{E}$ ) is the largest lagoon in Sri Lanka and it provides many services including fishing opportunities to the people in northern Sri Lanka. However, the status of the Jaffna lagoon fishery is not fully known at present due to the lack of detailed studies over the last 40 years. Therefore, this study was designed to fulfil this research gap. Both primary data and secondary data were used in this study. Primary data, including catch and fishing effort were collected at three major landing sites, Gurunagar, Paasaiyoor, and Kachchai by making fortnight field visits from March to December 2019. Secondary data of the monthly total catch and fishing effort were obtained from the district fisheries offices in

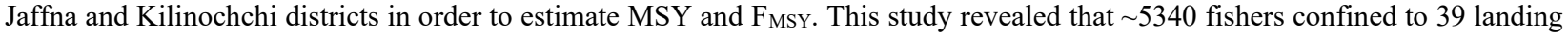
sites were actively engaged in lagoon fishing during the study period using 12 different fishing methods. Fyke nets (71\%) followed by stake nets $(10 \%)$, lagoon seines, and lagoon boat seines $(6 \%)$ are the widely used fishing methods in lagoon fisheries. Catch rates of major fishing gear were calculated and recorded as $\mathrm{kg}$ fisherman ${ }^{-1}$, day ${ }^{-1}$. Stake net $(37 \mathrm{~kg} \pm 7)$ reported a significantly higher catch rate than fyke net $(18 \mathrm{~kg} \pm 3)$, seine net $(17 \mathrm{~kg} \pm 6)$, and crab net $(16 \mathrm{~kg} \pm 3)(\mathrm{p}<0.05 ;$ ANOVA). Both mechanized $(59 \%)$ and non-mechanized (41\%) crafts are used in the lagoon fishing practices. Forty-six commercially important finfish and shellfish species belonging to 25 families were identified in the lagoon catches of which Penaeidae made the highest percentage contribution (27\%), followed by Siganidae (13\%), Mugilidae (11\%), Lethrinidae (10\%), and Gerreidae (9\%). Analysis of secondary data confirmed the increasing trend of fishing effort since 2009 but the total landings declined gradually after reporting its maximum value of $6958 \mathrm{Mt}$. in 2012. A rough estimate of maximum sustainable yield of the fishery of Jaffna lagoon was 6,694 Mt with the annual fishing effort (FMSY) of 1007 crafts. As the current fishing effort is higher than the F $_{M S Y}$, input control measures are recommended to utilize the lagoon fishery resources in a sustainable manner.
\end{abstract}

Keywords: Jaffna lagoon, Catch rate, Fishing methods, Maximum Sustainable Yield

\section{INTRODUCTION}

There are 82 coastal lagoons in Sri Lanka, which cover around $4 \%$ of the coastal waters of the country (Silva et al. 2013). These lagoons are associated with a variety of ecosystems, including mangroves, mudflats, and seagrass beds, providing many services in terms of cultural, economic, historical, and religious aspects. In addition, these habitats serve as breeding, nursery, and feeding grounds of aquatic organisms, especially shrimps, crabs, and fishes who contribute immensely to the lagoon fisheries (IUCNSL 2004; Miththapala 2013). The lagoon fishery has contributed to $6 \%$ of the coastal fish production in Sri Lanka in 2013, and one-third of this production was from the Jaffna lagoon (Silva et al. 2013).

The Jaffna lagoon $\left(9^{\circ} 50^{\prime} \mathrm{N}\right.$ and $79^{\circ} 50^{\prime} \mathrm{E}$ to $9^{\circ}$ $20^{\prime} \mathrm{N}$ and $80^{\circ} 30^{\prime} \mathrm{E}$ ) is the largest lagoon in Sri Lanka, and it is situated in the Jaffna and
Kilinochchi districts of the Northern Province. It is a semi-enclosed brackish water body, which opens into the northeastern part of Palk Bay as well as to the sea. The total area of the lagoon is about $450 \mathrm{~km}^{2}$ and its average depth is about $2 \mathrm{~m}$ (Chitravadivelu 1994). The shoreline of the lagoon is sandy, and the bottom is mostly muddy. Most of the shallow areas in the lagoon are dominated by dense vegetation, and an extensive seagrass bed was also reported (Digamadulla et al. 2016). A high diversity of fish and shellfish is reported in the lagoon, making a significant contribution to the fishery (IUCNSL and CEA 2006). Fishers from Jaffna and Kilinochchi districts, are engaged in fishing in the Jaffna lagoon and all the fishing activities are small-scale in nature and carried out as one-day operation.

Many recent studies have been reported in several coastal lagoons of Sri Lanka, including 


\section{N. Ragavan et al}

Negombo, Puttalam, and Koggala lagoons (Guruge et al. 2020; Jones et al. 2018; Wimalasiri et al. 2018). As, no intensive study has been carried out in the Jaffna lagoon after the civil war period, the current status of its fishery is not fully known. As such, this study was aimed at understanding the present status of the Jaffna lagoon fishery and determine its maximum sustainable yield (MSY) in order to provide baseline information required to manage and sustainable utilization of lagoon fishery resources.

\section{MATERIALS AND METHODS}

\section{Pilot survey}

A pilot survey was carried out in February 2019 to identify the fish landing sites around the Jaffna lagoon and the number of fishers engaged in lagoon fisheries.

\section{Data collection}

Both primary and secondary data were used in this study. Three major fish landing sites, namely Kurunagar $\left(9^{\circ} 39^{\prime} 00^{\prime \prime} \mathrm{N}, 80^{\circ} 01^{\prime} 09^{\prime \prime} \mathrm{E}\right)$, Paasaiyoor $\left(9^{\circ} 38^{\prime} 50^{\prime \prime} \mathrm{N}, 80^{\circ} 01^{\prime} 52^{\prime \prime} \mathrm{E}\right)$, and Kachchai $\left(9^{\circ} 38^{\prime}\right.$ $\left.28^{\prime \prime} \mathrm{N}, 80^{\circ} 12^{\prime} 17^{\prime \prime} \mathrm{E}\right)$ were selected based on the results of the pilot survey to collect primary data of catch, effort, and gear information (Figure 1).

Primary data were collected by making fortnight field visits to each landing site from March to December 2019. On each sampling day, 40-50 \% of crafts operated in the lagoon fishery were sampled randomly. Fish and shellfish were identified to the lowest possible taxon as soon as the catches were unloaded at the landing sites. Specimens, which were unable to identify, were preserved in $5 \%$ formalin and transported to the laboratory of the Department of Fisheries, University of Jaffna, for further identification.

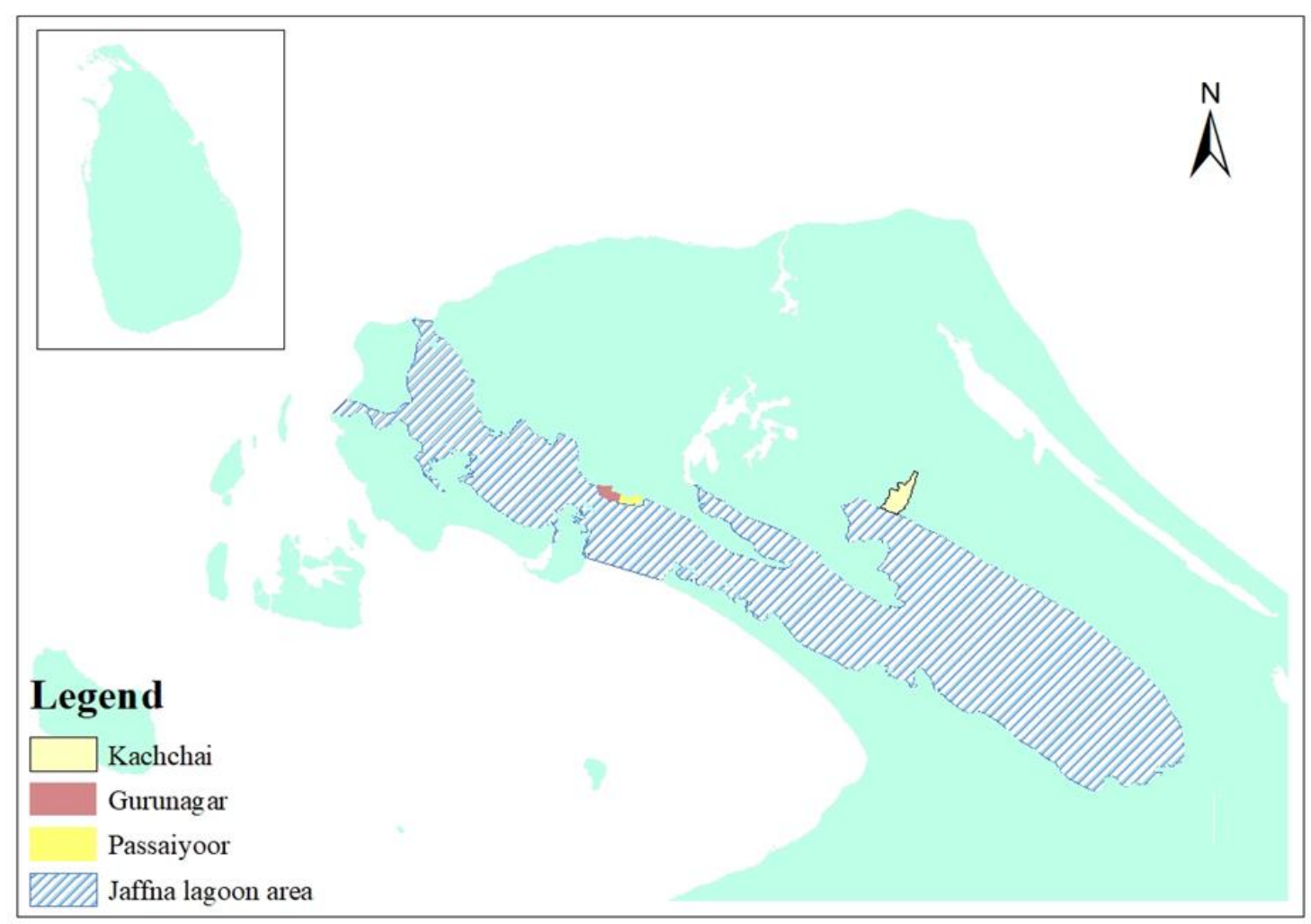

Fig 1 Landing sites selected for primary data collection in the Jaffna Lagoon

The total catch of each sampled boat was recorded with respect to major fish and shellfish families. The total number of crafts operated in the lagoon fishery at each landing site was also counted and recorded on each sampling day. Information on gear used, fishing location and fishing time was collected using questionnaires and semi-structured interviews. 


\section{N. Ragavan et al}

Secondary data, including monthly total catch and fishing effort (active number of fishing crafts) from January 2009 to December 2018, were collected. These data were mainly extracted from the monthly progress reports produced by the district fisheries offices of Jaffna and Kilinochchi.

\section{Data analysis}

Primary data were used to estimate monthly variations in catch rate $\left(\mathrm{kg}\right.$ fisherman $\left.{ }^{-1} \mathrm{day}^{-1}\right)$ and contributions of major finfish and shellfish families to the total fish landings. The number of active fishers, active crafts, and gear operated in each landing site were estimated using the data collected from the pilot study, questionnaires, and interviews. Secondary data were used to estimate the maximum sustainable yield (MSY) and effort at maximum sustainable yield ( $\mathrm{F}_{\mathrm{MSY}}$ ) of the Jaffna lagoon fishery.

\section{MSY and $\mathbf{F}_{\text {MSY }}$ estimation}

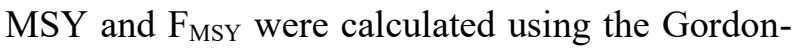
Schafer surplus production model. The model was constructed by plotting the predicted annual fish yield against the annual fishing effort following the steps given below;

In this analysis, fishing effort was defined as the number of active fishing crafts in the Jaffna lagoon fishery. Although different types of fishing crafts [i.e., Non-Mechanised Traditional Boats (NTRB), Mechanised Traditional Boats (MTRB), and Outboard Fiberglass Reinforced Plastic boats (OFRP); Figure 3] and 12 different types of fishing methods (Table 2) are operated in the lagoon, it was assumed that efforts for all types of fishing crafts and fishing methods remained the same throughout the period, and catch abilities of different types of

\section{RESULTS}

Information on fishers and fish landing sites in the Jaffna lagoon

A total of 5340 fishers belonging to Jaffna (5058) and Kilinochchi (282) districts were mainly crafts and fishing methods remained constant. Admittedly this is not a reasonable assumption. Nevertheless, this approach was employed to estimate approximate values of MSY and $\mathrm{F}_{\mathrm{MSY}}$ of the fishery of Jaffna lagoon.

Average number of active fishing crafts at a landing site was calculated by taking the mean of monthly average fishing effort obtained from the secondary data. Annual fishing effort (AFE) of the Jaffna lagoon was estimated by summing the average number of active fishing crafts at all landing sites. The annual fishing effort from 2008 to 2018 was estimated separately.

Annual fish landings at each landing site were estimated using the equation below (1)

$$
\mathrm{AFLL}=\sum_{\text {January }}^{\text {December }} M F L L
$$

where;

AFLL- Annual Fish Landings at the Landing site MFLL - Monthly Fish Landings at the Landing site

Annual fish yield (AFY) of the Jaffna lagoon was calculated by summing the annual fish landings of all landing sites around the Jaffna lagoon.

Average annual fish harvest per fishing craft (CPUE) was calculated using following equation.

$$
C P U E=\frac{A F Y}{A F E}
$$

The estimated annual CPUE value (average catch per craft per year in $\mathrm{kg}$ ) were plotted against annual fishing effort (average number of active crafts) and $a$ and $b$ were estimated from the line of best fit. The surplus yield curve was drawn through points representing the predicted yield by substituting the value of $a$ and the value of $b$ in the parabolic equation $Y=a f+b f^{2}$ for a range of arbitrarily chosen value for fishing effort $f$.

involved in lagoon fishing practices during the study period. They are confined to 39 landing sites in nine fisheries inspector divisions; Palai, Pooneryn, Chavakacheri, Jaffna east, Jaffna west, Sandilippai, Chulipuram, Kayts, and Velanai (Table1; Figure 2). 


\section{N. Ragavan et al}

Table 1 Number of lagoon fishers confined to different landing sites that come under 9 Fisheries Inspector (FI) divisions of Kilinochchi and Jaffna districts in 2019

\begin{tabular}{|c|c|c|c|}
\hline District & FI divisions & $\begin{array}{l}\text { Landing site/fishing } \\
\text { village }\end{array}$ & Number of lagoon fishermen \\
\hline \multirow{6}{*}{ Killinochchi } & \multirow{3}{*}{ Pooneryn } & Kowthari munai & 43 \\
\hline & & Nallur & 52 \\
\hline & & Nagathevanthurai & 72 \\
\hline & \multirow{3}{*}{ Palai } & Puloppalai & 31 \\
\hline & & Kilali & 56 \\
\hline & & Araththinagar & 28 \\
\hline \multirow{33}{*}{ Jaffna } & \multirow{9}{*}{ Chavakacheri } & Navatkuli west & 55 \\
\hline & & Navatkuli east & 67 \\
\hline & & Kaithadi Navatkuli South & 210 \\
\hline & & Maravanpulo & 59 \\
\hline & & Thanankilappu & 24 \\
\hline & & Kovilkudiyiruppu & 60 \\
\hline & & Meesalai & 41 \\
\hline & & Kachchai & 120 \\
\hline & & Ketpali & 51 \\
\hline & \multirow{6}{*}{ Jaffna East } & Paasaiyoor & 768 \\
\hline & & Columbuthurai & 64 \\
\hline & & Maniyamthoddam & 49 \\
\hline & & Poompukar & 90 \\
\hline & & Uthayapuram & 40 \\
\hline & & Ariyalai East & 22 \\
\hline & \multirow{4}{*}{ Jaffna west } & Kurunagar & 820 \\
\hline & & Koddadi & 72 \\
\hline & & Navanthurai & 290 \\
\hline & & Kokuvil West & 60 \\
\hline & Sandilippai & Kakkaitheevu & 50 \\
\hline & \multirow{10}{*}{ Chulipuram } & Ponnalai & 250 \\
\hline & & Moolai & 40 \\
\hline & & Arali west & 90 \\
\hline & & Arali centre & 110 \\
\hline & & Arali south & 40 \\
\hline & & Arali east & 400 \\
\hline & & Thoppukaadu & 50 \\
\hline & & Paalavodai & 35 \\
\hline & & Piddiyellai & 135 \\
\hline & & Ury & 230 \\
\hline & Kayts & Thampaddi & 350 \\
\hline & \multirow{2}{*}{ Velanai } & Cheddipulam & 26 \\
\hline & & Mandaitheevu & 290 \\
\hline
\end{tabular}




\section{N. Ragavan et al}

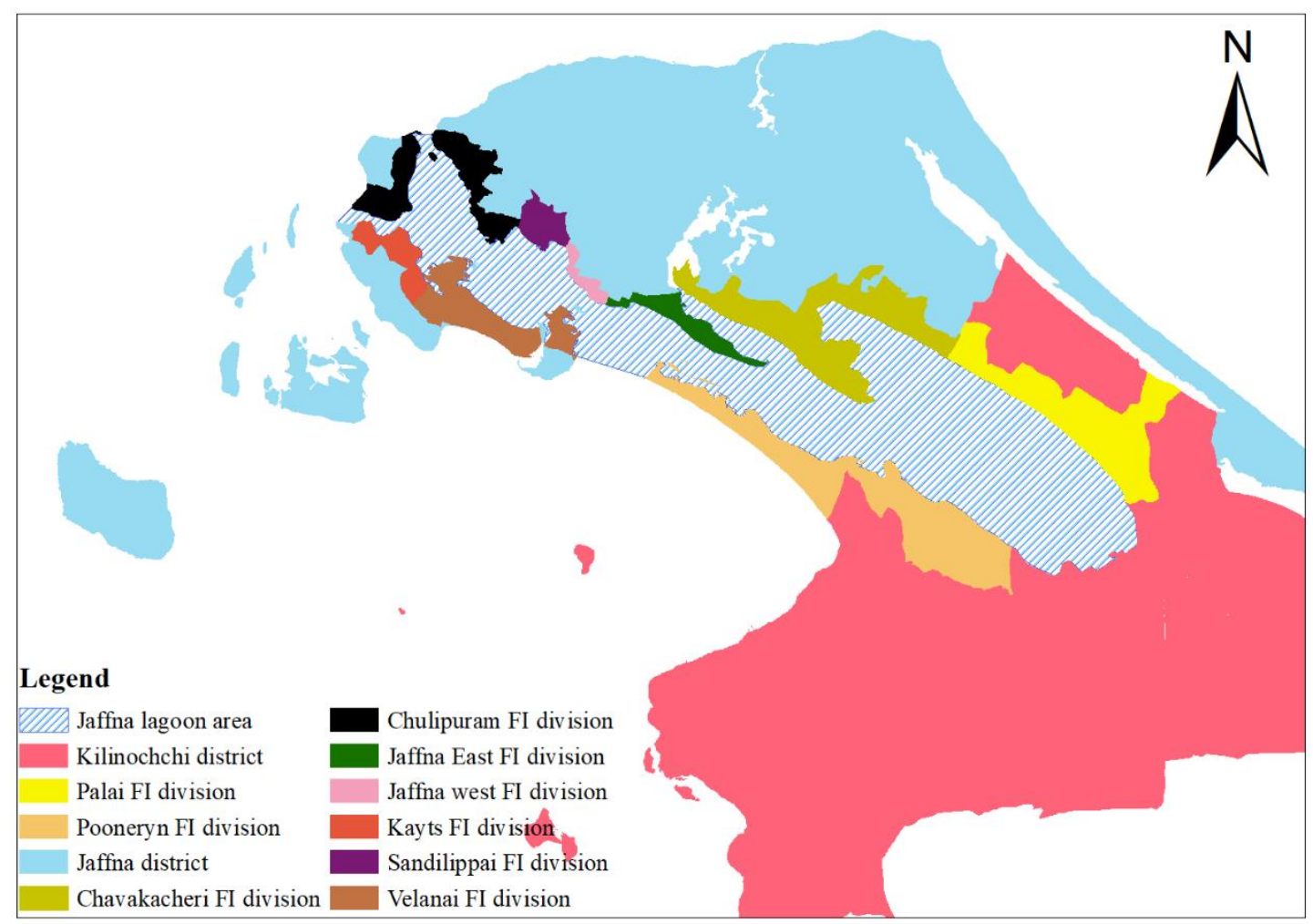

Fig 2 A map showing Fisheries Inspector (FI) Divisions of Jaffna lagoon

\section{Types of fishing crafts}

Three types of fishing crafts, Non-Mechanised Traditional Boat (NTRB), Mechanised Traditional Boat (MTRB), and Outboard Fiberglass Reinforced Plastic boat (OFRP) are used in the Jaffna lagoon fishery. It was evident that the use of mechanized fishing crafts $(59 \%)$ was higher than the nonmechanized crafts (Figure 3).

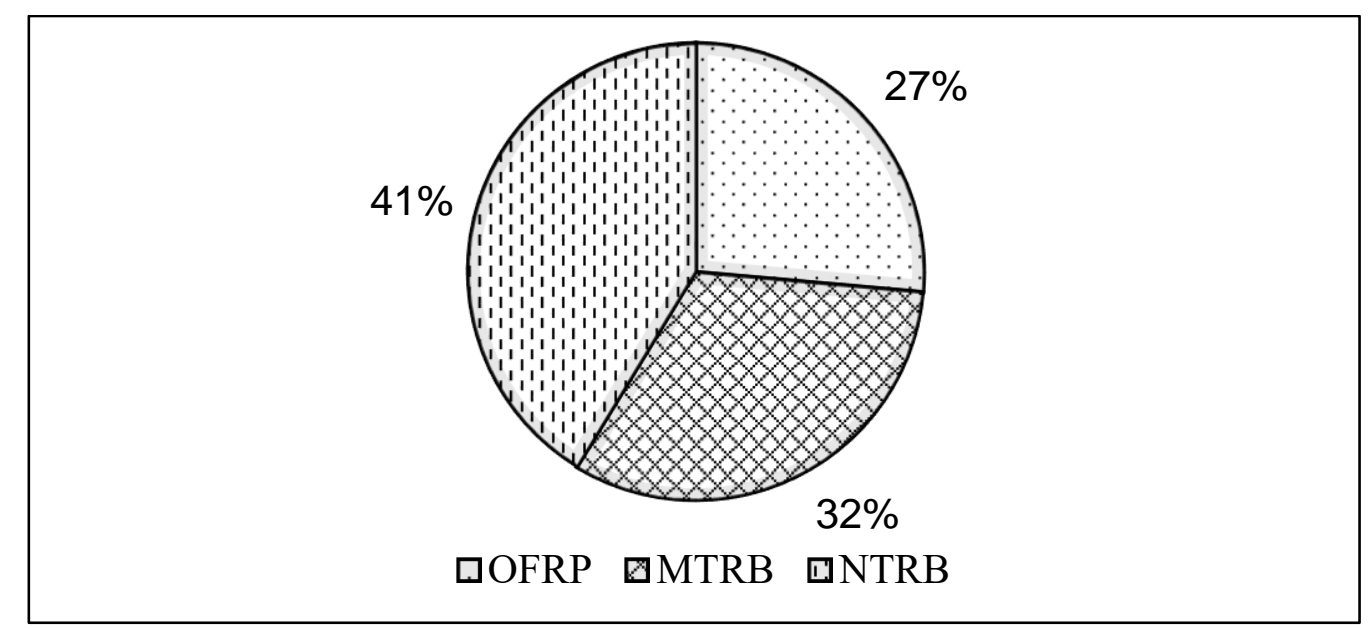

Fig 3 Percentage contribution of different types of fishing crafts to the Jaffna lagoon fishery. OFRP: Outboard Fiberglass Reinforced Plastic boats; MTRB: Mechanised Traditional Boats; NTRB: NonMechanised Traditional Boats 


\section{N. Ragavan et al}

\section{Types of fishing gear}

This study reported 12 different types of fishing gear operated in the Jaffna lagoon (Table 2) and widely used gear types include Fyke net (71\%), stake net $(10 \%)$, lagoon seines, and lagoon boat seines $(6 \%)$. Shrimp trap, cast net and hook and line are used by fishers in order to catch fish and shellfish for their day-to-day consumption. Fish trap (parikoodu) is an associate fishing gear commonly used with stake net, fyke net, and crab net, and $\sim 35 \%$ of fishers use these gear combinations at present. Fyke nets and lagoon seine mainly target shrimps, while finfish are targeted by the stake nets.

Both stake nets and fyke nets are fixed very close to the shore, therefore the fishing time is short and lasts around four hours. An average of three stake nets are possessed by a stake net fisher, and they do fishing around 20-24 days per month. The fyke net operation is restricted to 12-16 days per month, and a fisherman owns 5 sets of the net.

The seine nets are generally operated in the shallow regions of the lagoon from $7.00 \mathrm{pm}$ to the next day morning $(\sim 5.00 \mathrm{am})$. This fishing method is practised throughout the year, with an average of 15-18 fishing days per month. Usually, the seine nets are pulled by fishermen, but boats are used especially during the southwest monsoon period, as the force generated by fishermen is not enough to pull the net against the wind-driven strong currents.

Crab nets are operated around $1.5 \mathrm{~m}$ depth of the lagoon, and the gear is usually deployed at night, mainly around $7.00 \mathrm{pm}$, and the average fishing time varies from 7-10 hours. The crab fishing is carried out throughout the year, reporting an average of 15 to 20 fishing days per month.

Table 2 Different types of fishing gear used in the Jaffna lagoon fisheries and the percentage use of each gear by lagoon fishers in 2019

\begin{tabular}{lllc}
\hline No & Fishing method & Local name & \% usage by fishers \\
\hline 1 & Fyke net & Raal Koodu & $71 \%$ \\
2 & Stake net & Sirahu valai & $10 \%$ \\
3 & Lagoon seine & Raal iluvai & $6 \%$ \\
4 & Lagoon boat seine & Raal padaku iluvai & \\
5 & Crab net & Nandu valai & $5 \%$ \\
6 & Fish aggregating devices & Kulai poduthal & $4 \%$ \\
7 & Jig and line & Kanavai thoondil & \\
8 & Trammel net & Disco valai & $3 \%$ \\
9 & Cast net & Veechchu valai & $<1 \%$ \\
10 & Hook and line & Thoondil & $<1 \%$ \\
11 & Shrimp trap & Kandi & $<1 \%$ \\
12 & Fish trap & Parikoodu & $35 \%$ (Associate gear) \\
\hline
\end{tabular}

\section{Catch Per Unit Effort (CPUE)}

Monthly variations in catch rate (CPUE in $\mathrm{kg}$ fisherman ${ }^{-1}$ day $\left.^{-1}\right)$ were calculated with respect to different gear types (Figure 4). Stake net (37 \pm 7 ) reported a significantly higher catch rate than fyke net $(18 \pm 3)$, seine net $(17 \pm 6)$, and crab net $(16 \pm$ $3)(p<0.05$; ANOVA). Although it is difficult to see any clear pattern in the monthly variations in catch rate, all four gear types reported low catch rates, especially during the southwest monsoon period (May to September), and increasing trend was evident thereafter. 


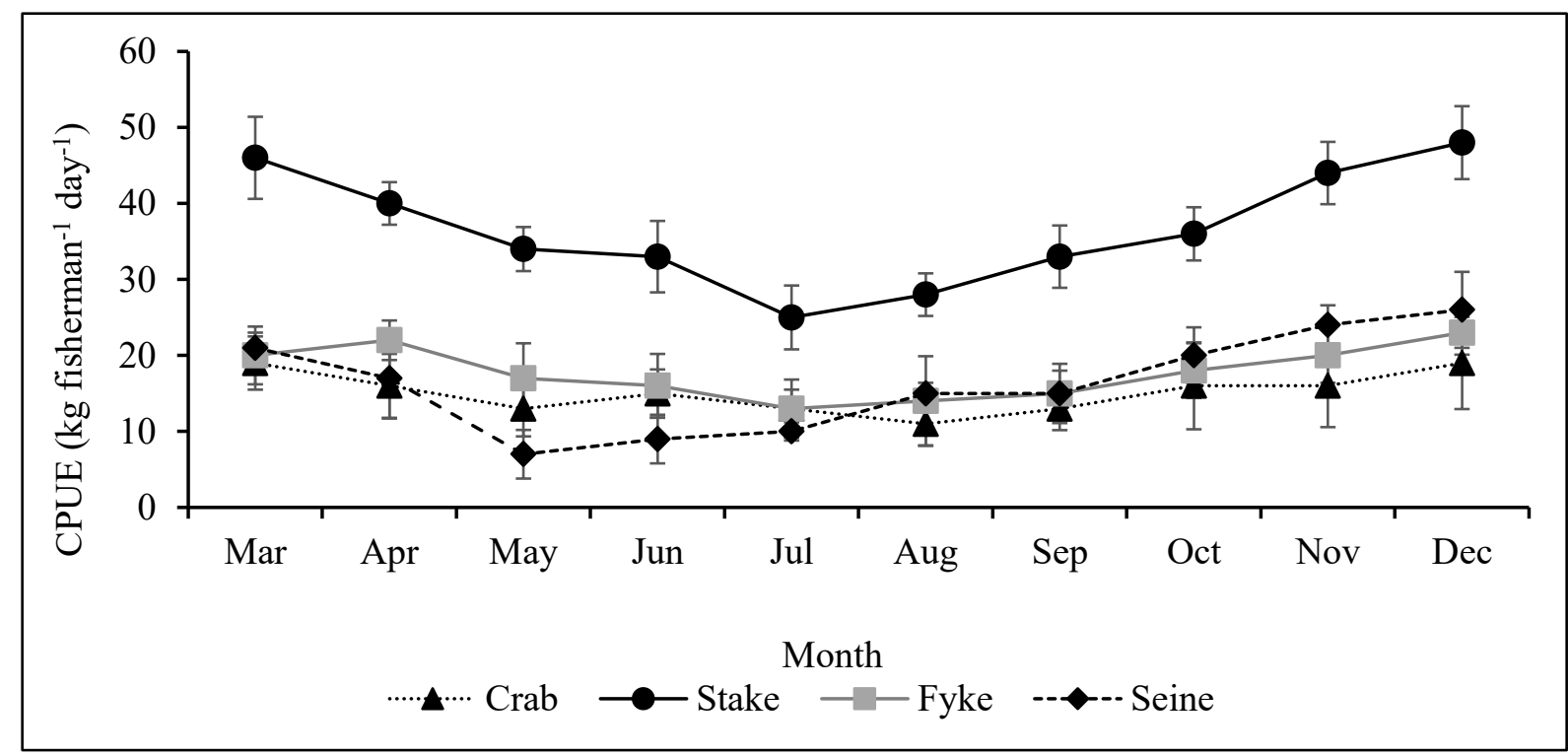

Fig 4 Monthly variations of catch rate (CPUE \pm SD in kg per fisherman per day) of stake net, fyke net, lagoon seine and Crab net operated in the Jaffna lagoon, from March to December 2019

\section{Commercially important finfish and shellfish species in the lagoon catches}

Forty-six commercially important finfish and shellfish species belonging to 24 families were identified during this study period. Among them, 35 species are fish, and the rest include shellfish representing shrimps and crabs (Table 3). The highest number of finfish species (4) was recorded under the family Siganidae. Three different species were reported under the families Carangidae, Gerreidae, and Leiognathidae, and two species for each were represented in the families Clupidae,
Hemiramphidae, Lutjanidae, Mugilidae, Plotosidae, and Terapontidae. Shellfish species were mainly reported under the families Penaeidae, Palinuridae, and Portunidae (Table 3). Six species; i.e. Penaeus semisulcatus, Penaeus latisulcatus, Penaeus japonicus, Penaeus indicus, Penaeus monodon and Metapenaeus dobsoni belonging to family Penaeidae were recorded in the lagoon catches. Scylla serrata, Portunus pelagicus and Thalamita crenata are the three identified crab species belonging to the family Portunidae.

Table 3 Commercially important fish and shellfish species reported in the Jaffna lagoon catches during the study period from March to December 2019.

\begin{tabular}{|l|l|}
\hline \multicolumn{1}{|c|}{ Family } & \multicolumn{1}{c|}{ Species name } \\
\hline Ariidae & Arius caelatus \\
\hline Belonidae & Strongylura leiura \\
\hline \multirow{4}{*}{ Carangidae } & Scomberoides lysan \\
\cline { 2 - 2 } & Carangoides gymnostethus \\
\cline { 2 - 2 } & Carangoides uii \\
\hline Carcharinidae & Scoliodon palasorrah \\
\hline Chanidae & Chanos chanos \\
\hline Cichlidae & Tilapia mossambica \\
\hline \multirow{2}{*}{ Clupidae } & Nematalosa nasus \\
\cline { 2 - 2 } & Sardinella albella \\
\hline Exocoetidae & Hirundichthys coromandelensis \\
\hline \multirow{3}{*}{ Gerreidae } & Gerres abbreviatus \\
\cline { 2 - 2 } & Gerres filamentosus \\
\cline { 2 - 2 } & Gerres acinaces \\
\hline
\end{tabular}

\begin{tabular}{|l|l|}
\hline Family & Species name \\
\hline \multirow{2}{*}{ Hemiramphidae } & Hemiramphus archipelagicus \\
\cline { 2 - 2 } & Hemiramphus far \\
\hline \multirow{3}{*}{ Leiognathidae } & Gazza achlamys \\
\cline { 2 - 2 } & Leiognathus daura \\
\cline { 2 - 2 } & Leiognathus fasciatus \\
\hline Lethrinidae & Lethrinus ornatus \\
\hline \multirow{2}{*}{ Loliginidae } & Sepioteuthis lessoniana \\
\hline \multirow{2}{*}{ Lutjanidae } & Lutjanus johnii \\
\hline \multirow{2}{*}{ Mugilidae } & Lutjanus russelli \\
\hline Mullidae & Valamugil buchanani \\
\cline { 2 - 2 } & Valamugil seheli \\
\hline Ostraciidae & Upeneus tragula \\
\hline
\end{tabular}




\begin{tabular}{|l|l|}
\hline Family & Species name \\
\hline \multirow{5}{*}{ Penaeidae } & Penaeus semisulcatus \\
\cline { 2 - 2 } & Penaeus latisulcatus \\
\cline { 2 - 2 } & Metapenaeus dobsoni \\
\cline { 2 - 2 } & Penaeus indicus \\
\cline { 2 - 2 } & Penaeus monodon \\
\cline { 2 - 2 } Plotosidae & Penaeus japonicus \\
\hline \multirow{2}{*}{ Portunidae } & Plotosus canius \\
\cline { 2 - 2 } & Plotosus lineatus \\
\hline & Scylla serrata \\
\cline { 2 - 2 } & Portunus pelagicus \\
\hline
\end{tabular}

Figure 5 shows the percentage contribution of dominant fish and shellfish families to the lagoon fish catches. Penaeidae made the highest percentage contribution (27\%), followed by Siganidae (13\%),

\begin{tabular}{|l|l|}
\hline \multirow{4}{*}{ Scaridae } & \\
\cline { 2 - 2 } Siganidae & Thalamita crenata \\
\hline \multirow{4}{*}{ Terapontidae } & Scarus niger \\
\cline { 2 - 2 } & Siganus lineatus \\
\cline { 2 - 2 } & Siganus javus \\
\cline { 2 - 2 } & Siganus vermiculatus \\
\cline { 2 - 2 } & Siganus canaliculatus \\
\hline Triacanthidae & Terapon puta \\
\cline { 2 - 2 } & Terapon jarbua \\
\hline
\end{tabular}

Mugilidae (11\%), Lethrinidae 10\%), and Gerreidae $(9 \%)$. The minimum contribution was reported by species belonging to the family Loligolidae (6\%).

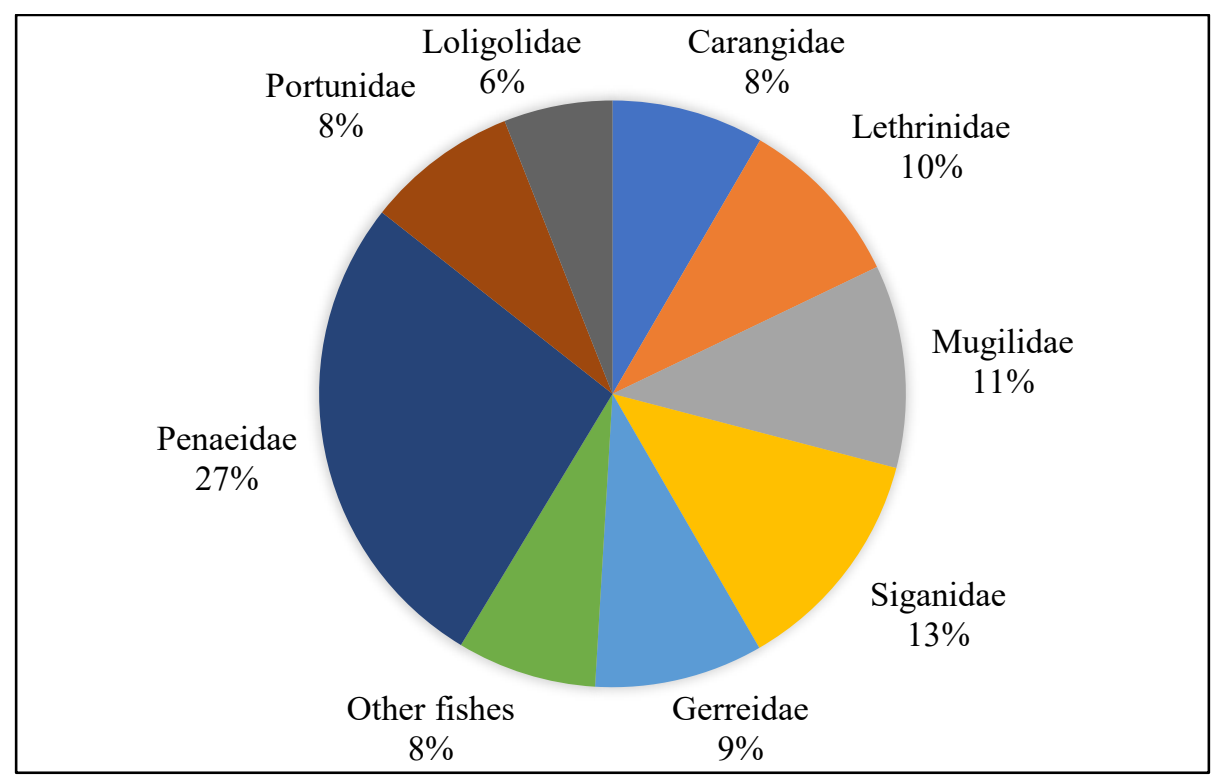

Fig 5 Percentage contribution of major fish and shellfish families to the total fish landings of Jaffna lagoon, from March to December 2019

\section{Variations in annual fishing effort and total lagoon catch}

Variations in annual fishing effort (number of active crafts) and the total catch of Jaffna lagoon for a period of ten years starting from 2009 are shown in Figure 6. An increasing trend of lagoon fishing effort was evident from 2009 to 2018. The total fish landings were started to increase from 2009, reported the maximum landings of $6958 \mathrm{Mt}$. in 2012, and gradually declined there after (Figure 6). Variations in CPUE with time marked the same pattern as the total fish landings. This analysis also proved the continuous decline of total catch as well as CPUE when increasing the fishing effort beyond the 1000 boats.

The relationship of annual CPUE against annual fishing effort from 2012 to 2018 showed a strong negative relationship (Figure 7) and this relationship was used to estimate the Schaefer yield curve shown in Figure 8. The estimated maximum sustainable yield of the Jaffna lagoon fishery is 6,694 Mt. and the maximum number of crafts recommended to harvest this yield is ( $\left.\mathrm{F}_{\mathrm{MSY}}\right)$ is 1007 . The current fishing effort is higher than the recommended level. 
N. Ragavan et al

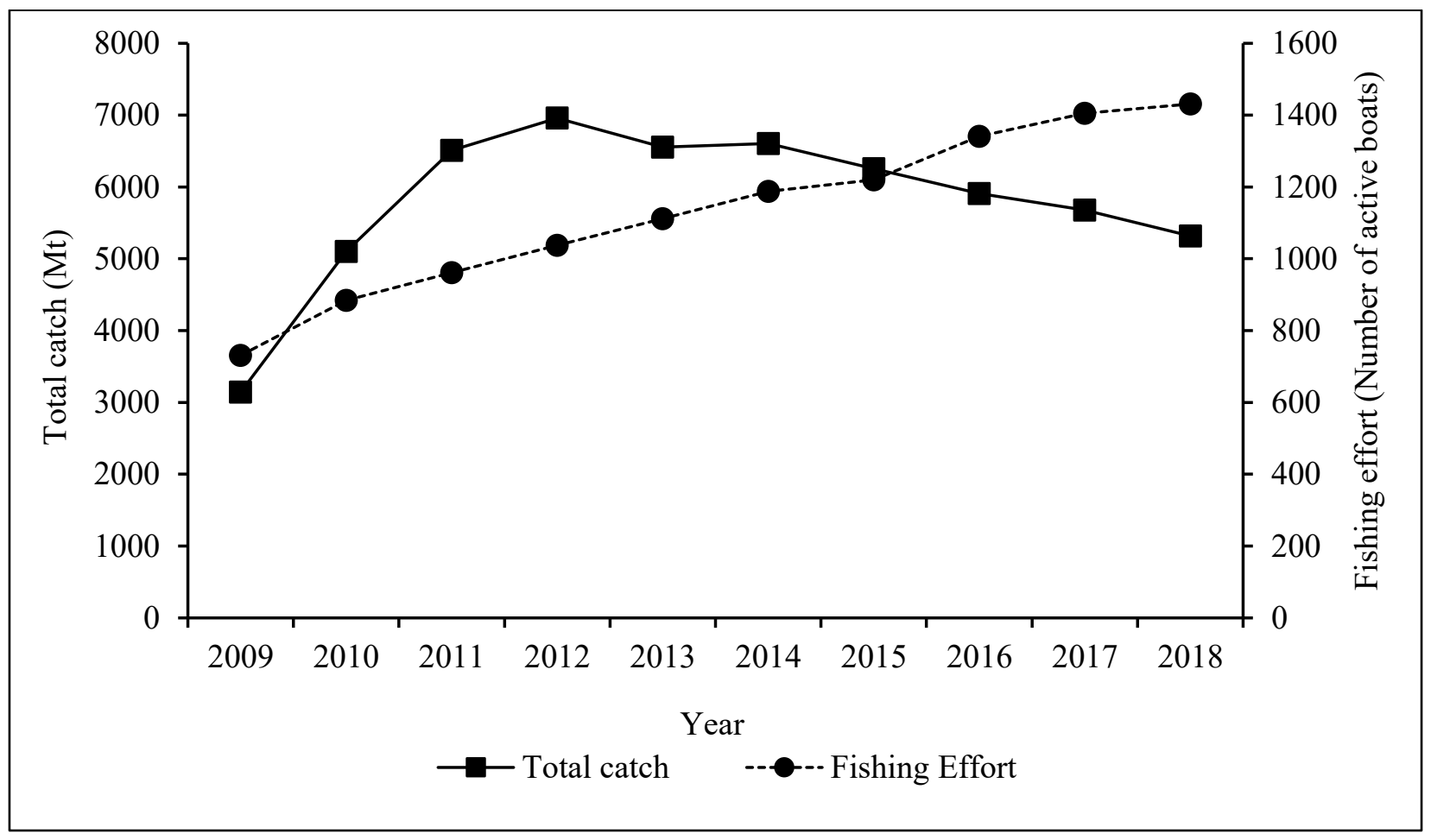

Fig 6 Variation in annual fishing effort and fish landings of the Jaffna lagoon from 2008 to 2018

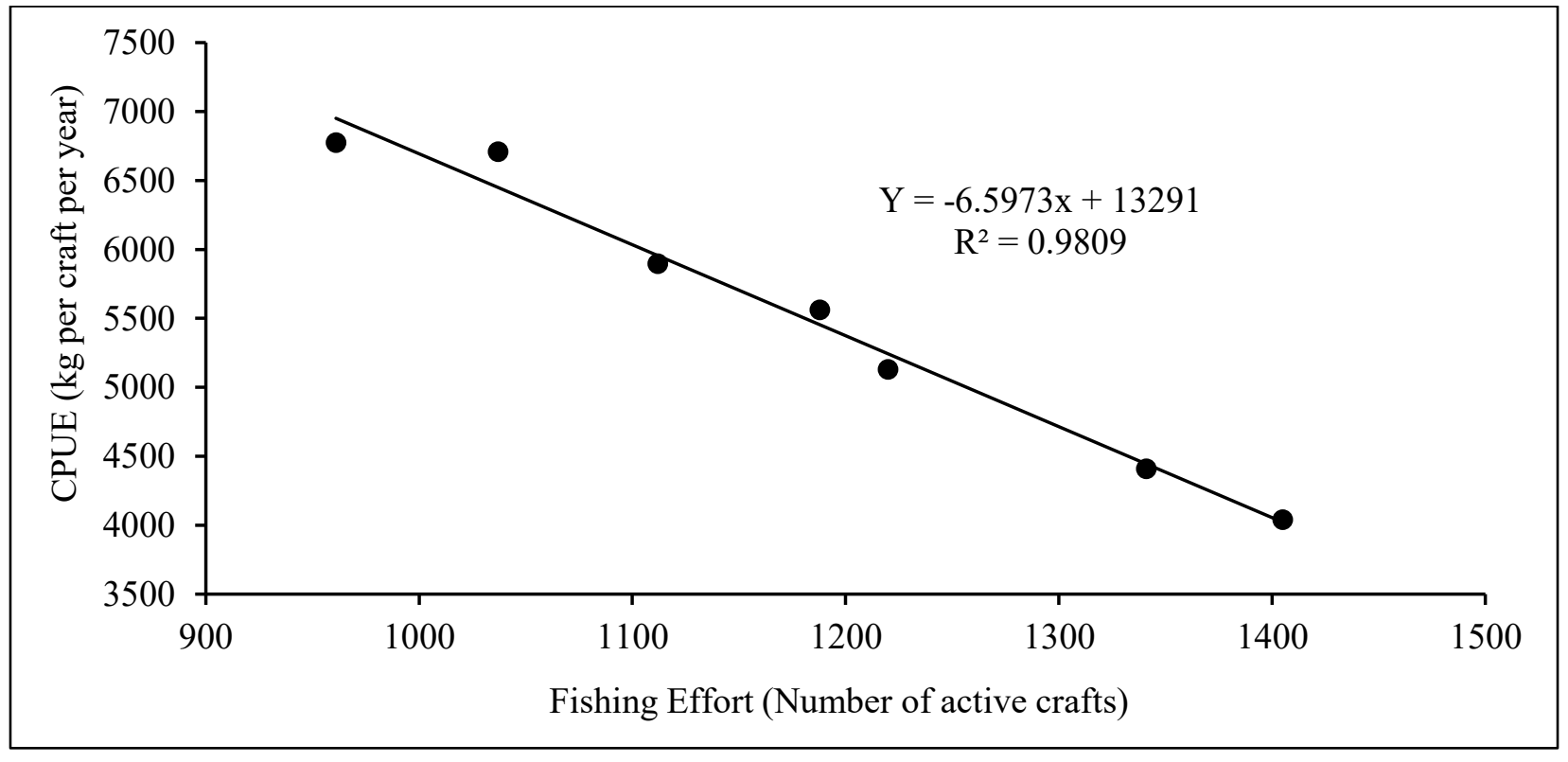

Fig 7 Regression relationship between CPUE (catch per crafts per year in $\mathrm{kg}$ ) and fishing effort (number of active crafts) in the Jaffna lagoon fishery from 2012 to 2018 


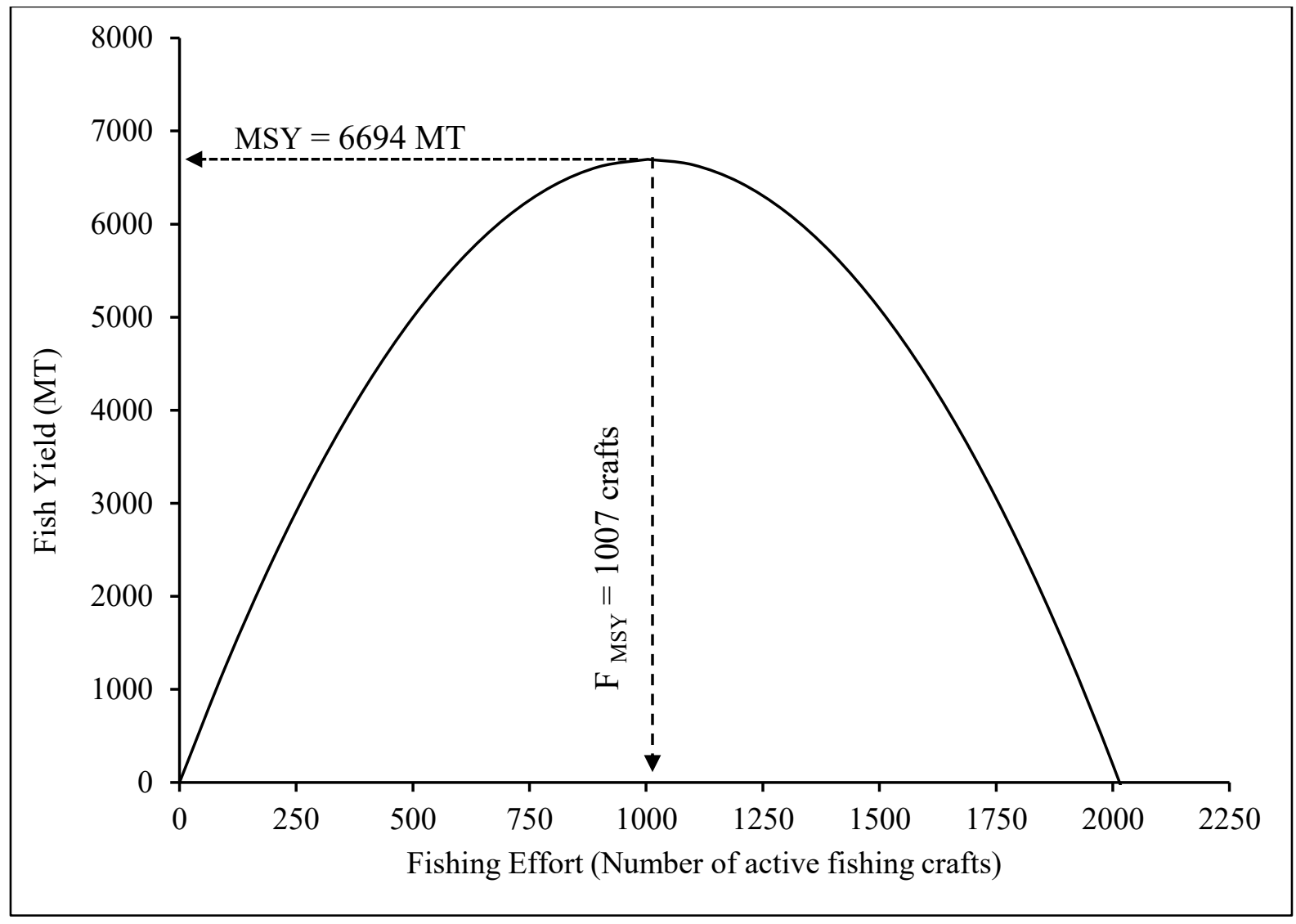

Fig 8 Schaefer yield curve obtained for the Jaffna lagoon fishery with estimated MSY and F $_{\text {MSY }}$

\section{DISCUSSION}

The number of active fishers in the Jaffna lagoon is higher than the number of fishers reported in the Negombo (3310) and Chilaw lagoon (1329), and lower than in Puttlam lagoon (5926) (DFAR 2012; DFAR 2013a). The reported higher number of lagoon fishers in Jaffna than Kilinochchi districts could be associated with the geographical position of the lagoon. The use of different types of crafts in lagoon fisheries has been reported in other lagoons including Puttalam, Negombo and Kokkilai (Maheepala et al. 2017; NARA 2017). According to the results of the present study, mechanized crafts are widely used in the Jaffna lagoon fishery. There are many reasons for this observation. The fyke nets and some other lagoon fishing gears (i.e., crab nets and fish aggregating devices) are operated far away from the shore, especially in Gurunagar and Navanthurai areas and the use of mechanized crafts makes these operations easier and faster than the non-mechanized crafts. Further, some selected lagoon fishers were given outboard engines as a subsidy and this promoted mechanization of the NTRB fishing crafts in the lagoon. Meanwhile, OFRP boats were given to the selected beneficiaries, especially those who were registered as 'resettle fishers' and this process also contributed to increase the number of mechanized fishing crafts in the lagoon.

This study identified 12 different fishing methods operated in the Jaffna lagoon. Although the use of gill nets and pots to catch cephalopods was reported previously (Thivviyan and Jayakody 2016; Kuganathan et al. 2009), these fishing methods were not reported in this study. Some possible reasons for this observation include changing of these gear types either due to the low abundance of target species or poor economic return of these fishing practices. Although Parikoodu, stake net, drag net (lagoon seine net), hoop net, drift net, and trammel net have been used to harvest shrimps and crabs in the Jaffna lagoon for long time (Chitravadivelu 1990, 1994), hoop net and drift net 


\section{N. Ragavan et al}

are not used at present. However, this study noted the use of hoop nets to make fyke nets in combining with the stake nets. Cast net and hand line are practiced in the lagoon as subsistence fishing activities without the support of any fishing craft. The use of diverse fishing methods such as stake net, fyke net, cast net, hand line, seine net, and crab nets is a common practice in the lagoon fisheries in Sri Lanka (Sanders et al. 2000; Atapattu and Nissanka 2005). However, the lagoon boat seine and Kandi fishing methods seem to be unique to the Jaffna lagoon fishery. When compared with previous statistics, a significant reduction of Kandi fishing operations was reported at present (Naafir 2018). This could be due to a lack of skilled personnel to construct and operate this fishing gear or its poor economic return.

This study reports the presence of 46 commercially important finfish and shellfish species in the Jaffna lagoon, and similar results were previously reported by Thivviyan and Jayakody (2016). Although Shobiga (2015) recorded one hundred finfish in the Jaffna lagoon, all of them were not commercially important species and some were reported rarely in the catches while others reported very low economic value. This study reports that fish and shellfish belonging to the families Penaeidae, Siganidae, Mugilidae, Lethrinidae, Gerreidae, Carangidae, Portunidae, and Loligolidae are dominant in the lagoon catches and similar observations have been reported previously in the Jaffna lagoon by Sivalingam (2005), Thivviyan and Jayakody (2016). Similar species composition has been reported in the lagoon catches of Negombo (Wimalasiri et al. 2018), Chilaw (DFAR 2013a) and Puttalam (DFAR 2013b). According to Jayawickrema (1987), penaeid shrimps spend part of their life cycle in brackish water estuaries and lagoons, and this could be the possible reason for their high contribution to the lagoon catches. Siluvaithasan and Stokke (2006) reported that the connection of the Jaffna lagoon with the prawn bank of the Palk bay also ensures the high abundance of shrimps in the lagoon. On the other hand, fishers may target shrimps than fish due to their high market value and this also contributes to their high abundance in the commercial catches.

The observed low lagoon production during May to October could be due interuption of fishing activities with the onset of southwest monsoon. According to Silva et al. (2013), contribution of the
Jaffna lagoon fishery to the total coastal fish production in Sri Lanka is significant and it was 2\% in 2018 (NARA 2018). This study also reported high annual production $(5000-6000 \mathrm{Mt})$ in the Jaffna lagoon during the period of 2010-2018. The lifting of fishing restrictions (i.e., the number of active crafts, number of fishing days, number of fishing hours, and fishing distance) imposed during the civil war period could be the main reason for this high production. The observed trend in the fishing effort is also associated with the resettlement of fishers, existed subsidiary schemes to provide fishing crafts, and total lifting of fishing restrictions in the lagoon. However, according to the Schafer model, the current fishing effort is reported to be higher than the estimated $\mathrm{F}_{\mathrm{MSY}}$, therefore input control is suggested for the sustainable utilization of lagoon fishery resources. Though there are some uncertainties on the reliability of catch and effort statistics used in the Schaefer model, the estimated values can be used as baseline information to propose and implement some management measures to this data-poor fishery. It must be noted that in the present study, Schaefer surplus yield model was employed without standardization of fishing effort, which essentially consisted of three types of crafts and 12 types of fishing methods. As

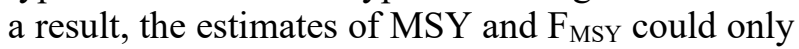
be treated as rough approximations for preliminary management purposes. Further, the information on fish landing sites, number of fishers, crafts and gear used, lagoon catch composition and production trend will be important to update the lagoon fisheries statistics in Sri Lanka.

\section{REFERENCE}

Atapattu, U. \& C. Nissanka 2005. Present status of the fishery in Rekawa lagoon, Sri Lanka. Proceeding of Third Science Symposium (3), pp. 42-52. Matara

Chitravadivelu, K. 1990. Efficiency of the main fishing gears used in prawn fishery in the Jaffna lagoon. Journal of the National Science Council of Sri Lanka, 18(1): 37-52.

Chitravadivelu, K. 1994. Aspects of fishery and species composition of edible crabs in the Jaffna Lagoon. Journal of the National Science Council of Sri Lanka, 22(1): 43-55.

DFAR 2012. Fisheries development and management plan of Negombo lagoon. 


\section{N. Ragavan et al}

Regional Fisheries Livelihoods Programme for South and Southeast Asia (GCP/RAS/237/SPA): Field Project Document 2012/LKA/CM/12, 35 p.

DFAR 2013a. Fisheries development and management plan of Chilaw lagoon. Regional Fisheries Livelihoods Programme for South and Southeast Asia (GCP/RAS/237/SPA): Field Project Document 2013/LKA/CM/2, 32 p.

DFAR 2013b. Fisheries development and management plan of Puttalam lagoon. Regional Fisheries Livelihoods Programme for South and Southeast Asia (GCP/RAS/237/SPA): Field Project Document 2013/LKA/CM/2, 36 p.

Digamadulla, K. S., Kuganathan, S. \& A. Thavaranjit 2016. Spatiality and species diversity of critical seagrass population in curvier basin of Jaffna lagoon at coherent Mandaitheevu coastline. Proceeding of the 5th YSF Symposium, p. 24.

Guruge, S., Herath, H. \& I. Wickramaratne 2020. Study on Illegal Fishing Practices Used for Exploitation of Fishery Resources in the Koggala Lagoon, Sri Lanka. Proceedings of the International Research Conference of Uva Wellassa University, p. 99.

IUCNSL and CEA 2006. National Wetland Directory of Sri Lanka, Colombo, p. 342.

IUCNSL 2004. Wetland Conservation in Sri Lanka. Sri Lanka, Proceedings of the National Symposium on Wetland Conservation and Management, p. iii+75pp.

Jayawickrema, S.J.C 1987. Study of the population dynamics of Indian white shrimp Penaeus indicus (H. Milne Edward) in Negombo and Chilaw, Sri Lanka during the period September 1982 to June 1986. Diploma thesis. Norway: University Bergen.

Jones, B. L., Unsworth, R. K. F., Udagedara, S. \& L.C. Cullen-Unsworth 2018. Conservation Concerns of Small-Scale Fisheries: By-Catch Impacts of a Shrimp and Finfish Fishery in a Sri Lankan Lagoon. Frontiers in Marine Science, 5: Article 52. https://doi.org/10.3389/fmars. 2018.00052

Kuganathan, S. Sivashanthini, K., Charles, G. \& W. Thulasitha 2009. Length-weight relationship and growth pattern of Sepioteuthis lessoniana (Cephalopoda: Teuthida) from the Jaffna lagoon, Sri Lanka. Journal of biological science, 9(4): 357-361.

Maheepala, M., De. Silva, D., Sandaruwan, K. \& K. Amaralal 2017. An insight into livelihood aspects of Puttalam Lagoon fishery. Proceedings of the National Aquatic Resource Research and Development Agency, Scientific Session 2017, 68 p.

Miththapala S. 2013. Lagoons and Estuaries. Coastal Ecosystems Series (Vol 4). IUCN Sri Lanka Country Office, Colombo. vi $+73 \mathrm{p}$.

Naafir, E. 2018. Assess the biological and fisheries dimension of fyke net shrimp fishery at Columbuthurai, Jaffna lagoon, Jaffna: Department of Fisheries, University of Jaffna.

NARA 2017. Socio-Economic aspects of Kokkilai lagoon fishery

NARA 2018. Sri Lanka Fisheries Industry Outlook, Colombo: NARA.

Sanders, M., Jayawardena, A. \& S. Ediriweera 2000. Preliminary assessment for the shrimp fisheries of the Negombo Lagoon (Sri Lanka), Rome: FAO Fisheries Circular. No. 958, FAO.

Shobiga, V. 2015. Finfish composition of wing net catches from the Jaffna lagoon, Jaffna: Department of Zoology, University of Jaffna.

Siluvaithasan, A. \& K. Stokke 2006. Fisheries under fire: Impacts of war and challenges of reconstruction and development in Jaffna fisheries, Sri Lanka. Norwegian Journal of Geography, 60: 240-248.

Silva, E. I. L., Katupotha, J., Amarasinghe, O., Manthrithilake, H. \& R. Ariyaratna 2013. Lagoons of Sri Lanka: from the origins to the present. Colombo, Sri Lanka: International Water Management Institute (IWMI). 122 p.

Sivalingam, S. 2005. General features and fisheries potential of Palk bay, Palk strait and its environs. Journal of National Science Foundation of Sri Lanka, 33(4): 225-232.

Thivviyan, S. \& D. Jayakody 2016. Assessment on the present status of coastal fisheries at Gurunagar, Jaffna. Vingnanam Journal of Science, 12(1\&2): 18-31.

Wimalasiri, H., Perera, H. \& R. Jayathilaka 2018. The current status of Negombo Lagoon fishery. Colombo, National Aquatic Resources Research and Development Agency (NARA) International Scientific Sessions, p. 20. 